\title{
Synthesis of $\boldsymbol{N}$-perfluoroalkyl-3,4-disubstituted pyrroles by rhodium-catalyzed transannulation of $\mathbf{N}$-fluoroalkyl- 1,2,3-triazoles with terminal alkynes
}

\author{
Olga Bakhanovich ${ }^{1,2}$, Viktor Khutorianskyi ${ }^{1}$, Vladimir Motornov ${ }^{1}$ and Petr Beier ${ }^{* 1}$
}

\section{Full Research Paper}

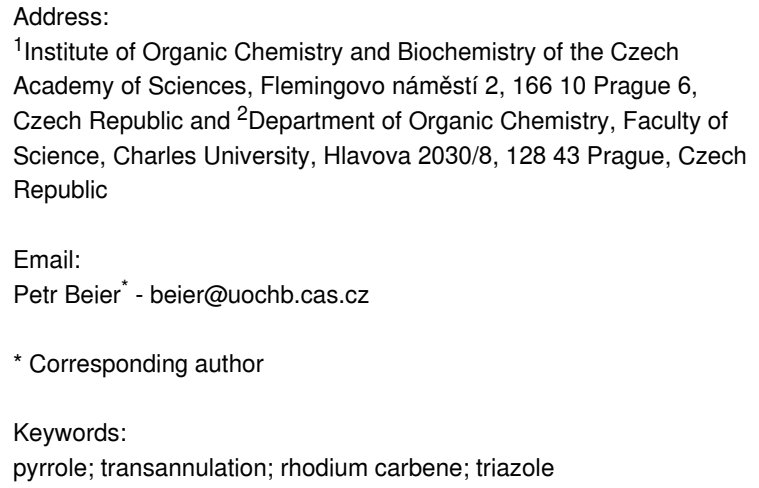

${ }^{1}$ Institute of Organic Chemistry and Biochemistry of the Czech Academy of Sciences, Flemingovo náměstí 2, 16610 Prague 6, Czech Republic and ${ }^{2}$ Department of Organic Chemistry, Faculty of Science, Charles University, Hlavova 2030/8, 12843 Prague, Czech Republic

Email:

Petr Beier* - beier@uochb.cas.cz

* Corresponding author

Keywords:

pyrrole; transannulation; rhodium carbene; triazole

\author{
Beilstein J. Org. Chem. 2021, 17, 504-510. \\ https://doi.org/10.3762/bjoc.17.44 \\ Received: 01 December 2020 \\ Accepted: 10 February 2021 \\ Published: 18 February 2021 \\ Associate Editor: I. Marek \\ (C) 2021 Bakhanovich et al.; licensee Beilstein-Institut. \\ License and terms: see end of document.
}

\begin{abstract}
The rhodium-catalyzed transannulation of $N$-perfluoroalkyl-1,2,3-triazoles with aromatic and aliphatic terminal alkynes under microwave heating conditions afforded $N$-perfluoroalkyl-3,4-disubstituted pyrroles (major products) and $N$-fluoroalkyl-2,4-disubstituted pyrroles (minor products). The observed selectivities in the case of the reactions with aliphatic alkynes were high.
\end{abstract}

\section{Introduction}

Pyrroles are known to be important structural moieties appearing in natural products, synthetic drugs, agrochemicals, and functional materials (polymers, dyes, films, etc.) (Figure 1) [1-4]. Numerous methods exist for pyrrole synthesis, including the classical and industrially important condensation approaches, such as the Hantzsch, Huisgen, and Paal-Knorr processes [5]. However, the direct modification of pyrroles to the 3,4-disubstituted derivatives is challenging because an electrophilic aromatic substitution of pyrroles or the metalation of $\mathrm{N}$-substituted pyrroles and the subsequent reaction with electrophiles take place in position two of the ring [6,7].

Recently, $N$-sulfonyl-1,2,3-triazoles, conveniently prepared by $[3+2]$ cycloadditions of terminal alkynes with sulfonyl azides, have been used as the precursors to $N$-sulfonylindoles by transition-metal-catalyzed transannulation reactions. In the presence of $\mathrm{Rh}(\mathrm{II})$ or $\mathrm{Ni}(0)$ catalysts the triazole ring-opening takes place and intermediate highly electrophilic metal-bound iminocarbenes form. These iminocarbenes undergo a variety of intriguing reactions, such as a cycloaddition and a $\mathrm{C}-\mathrm{H}$ functionalization, among others, leading mostly to nitrogen heterocycles [8-10]. Using this chemistry, a variety of pyrroles have been prepared starting from $N$-sulfonyl-1,2,3-triazoles (Scheme 1) [11-17].

We have recently reported that $N$-perfluoroalkyl-1,2,3-triazoles [18] undergo rhodium-catalyzed transannulation reactions leading to various nitrogen heterocycles, such as imidazoles, 


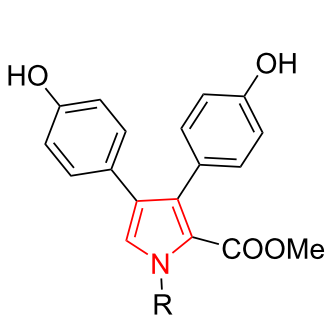

lamellarins cytotoxic alkaloids<smiles>CC(C)c1c(C(=O)Nc2ccccc2)c(-c2ccccc2)c(-c2ccc(F)cc2)n1CCC(O)CC(O)CC(=O)O</smiles>

atorvastatin used to lower LDL cholesterol levels<smiles>CCNCCNC(=O)c1c(C)[nH]c(/C=C2\C(=O)Nc3ccc(F)cc32)c1C</smiles>

sunitinib anticancer<smiles>O=C(c1ccccc1)c1ccc2n1CCC2C(=O)O</smiles>

ketorolac anti-inflammarory<smiles>N#Cc1c[nH]cc1-c1cccc2c1OC(F)(F)O2</smiles>

fludioxonil fungicide

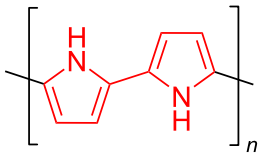

polypyrrole conducting polymer

Figure 1: Selected pyrrole-containing natural products, drugs, agrochemicals, and functional materials.

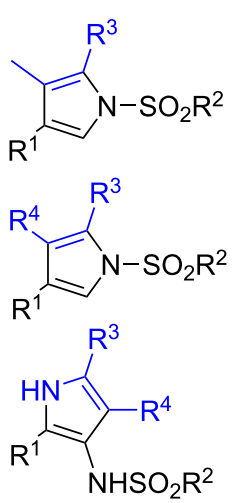<smiles>[R]C=CCC</smiles><smiles>[R]#CC(C)C#[R]C</smiles>

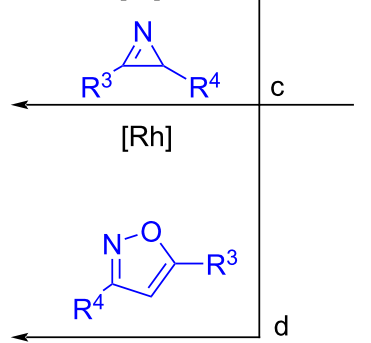

$[\mathrm{Rh}]$<smiles>[R17]1cccc1</smiles><smiles>[GeH3]</smiles>
$-\mathrm{N}_{2} \downarrow \begin{aligned} & {[\mathrm{Rh}(\mathrm{II})]} \\ & \mathrm{or}[\mathrm{Ni}(0)]\end{aligned}$ $\left[\stackrel{[\mathrm{M}]}{\mathrm{L}}=\mathrm{N}-\mathrm{SO}_{2} \mathrm{R}^{2}\right]$<smiles>[R]OS(=O)Nc1c([R])c[nH]c1[R]</smiles>

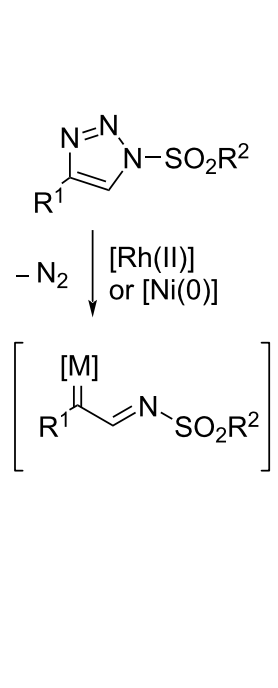

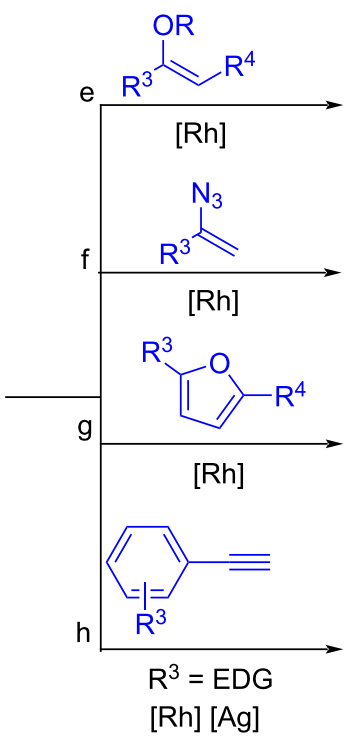<smiles>[R][R]O[S+]([R])(=O)n1cc([R])cc1[R]</smiles><smiles>[R][R]S(=O)O[Y5]([R2])(=O)n1cc([R])c(CC([R4])=O)c1[R]</smiles>

Scheme 1: Transformation of $N$-sulfonyl-1,2,3-triazoles to pyrroles via metal iminocarbenes.

pyrrolones, imidazolones, oxazoles, azepines [19-22], and pyrroles [19].

The use of fluorine atoms and fluoro groups (including the trifluoromethyl group) is a widely used strategy to improve the properties of drug candidates or agrochemicals [23-28]. The development of new methods for the synthesis of selectively fluorinated and trifluorometylated compounds is essential for future progress in areas that eventually improve the quality of life. In this context, $\mathrm{N}$-trifluoromethylated compounds (amines, amides and nitrogen heterocycles) are a relatively underexplored group of molecules with a high potential in medicinal chemistry [29,30]. Taking inspiration from the work of Gevorgyan (Scheme 1h) [11], we report herein our recent results on the rhodium-catalyzed transannulation of $\mathrm{N}$-perfluoroalkyl-1,2,3triazoles with terminal alkynes leading to unusually substituted $N$-perfluoroalkylpyrroles.

\section{Results and Discussion}

The published transannulation of $\mathrm{N}$-tosyl-1,2,3-triazoles with terminal alkynes requires the use of a $\mathrm{Rh} / \mathrm{Ag}$ binary catalyst system, works only with electron-rich arylacetylenes and 
leads to $N$-tosyl-2,4-disubstituted pyrroles (Scheme 1h) [11]. The application of these conditions to $N$-trifluoromethyltriazole 1a and phenylacetylene leads to a mixture of 3,4diphenylpyrrole 2a and 2,4-diphenylpyrrole 2a'. However, repeating the experiment without the silver catalyst afforded the same results showing that the silver catalyst was not necessary in our case and that the product regioselectivity was not dependent on the silver catalyst (Table 1, entry 1). Chloroform was found to be the most suitable solvent and varying rhodium catalysts led to the $\mathbf{2 a}+\mathbf{2 a}$ ' product mixture of various ratios. $\mathrm{Rh}_{2}$ (oct) $)_{4}$ and $\mathrm{Rh}_{2}(\mathrm{esp})_{2}$ gave the highest $\mathbf{2 a} / \mathbf{2 a}$ ' ratio, while the electron-deficient $\mathrm{Rh}_{2}(\mathrm{pfb})_{4}$ catalyst gave the lowest $\mathbf{2 a} / \mathbf{2 a}$ ' ratio and an incomplete conversion. Reducing the reaction temperature to $80{ }^{\circ} \mathrm{C}$ afforded a full conversion of the starting triazole, but no reaction took place at $60{ }^{\circ} \mathrm{C}$. The optimized conditions are presented in Table 1, entry 8; however, for the following reaction scope study, a temperature of $100{ }^{\circ} \mathrm{C}$ and 20 min reaction time were used to ensure a full conversion for all studied substrates.

Next, the transannulation reaction was tested using a range of different substituted $N$-trifluoromethyl- and $N$-pentafluoroethyl4-aryl-1,2,3-triazoles 1 with phenylacetylene (Scheme 2). Good

Table 1: Reaction conditions screening of the transannulation of triazole 1a with phenylacetylene.

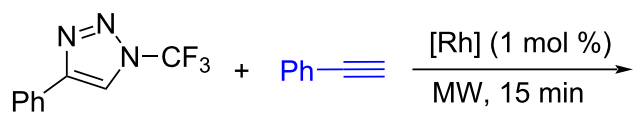

1a

(3 equiv)<smiles>FC(F)(F)n1cc(-c2ccccc2)c(-c2ccccc2)c1</smiles>

2a<smiles>FC(F)(F)n1cc(-c2ccccc2)cc1-c1ccccc1</smiles>

$2 a^{\prime}$

\begin{tabular}{|c|c|c|c|c|c|}
\hline Entry & {$[\mathrm{Rh}]$} & Solvent & Temp. $\left({ }^{\circ} \mathrm{C}\right)$ & Conv. $(\%)^{a}$ & $2 a / 2 a$ \\
\hline $1^{b}$ & $\mathrm{Rh}_{2}(\mathrm{oct})_{4}$ & cyclohexane & 120 & 90 & $75: 25$ \\
\hline 2 & $\mathrm{Rh}_{2}(\mathrm{oct})_{4}$ & $\mathrm{CHCl}_{3}$ & 120 & 100 & $60: 40$ \\
\hline 3 & $\mathrm{Rh}_{2}(\mathrm{OAc})_{4}$ & $\mathrm{CHCl}_{3}$ & 120 & 100 & $34: 66$ \\
\hline 4 & $\mathrm{Rh}_{2}(\mathrm{esp})_{2}$ & $\mathrm{CHCl}_{3}$ & 120 & 100 & $75: 25$ \\
\hline 5 & $\mathrm{Rh}_{2}(\mathrm{pfb})_{4}$ & $\mathrm{CHCl}_{3}$ & 120 & 54 & $14: 86$ \\
\hline 6 & $\mathrm{Rh}_{2}(\mathrm{esp})_{2}$ & $\mathrm{CHCl}_{3}$ & 100 & 100 & $75: 25$ \\
\hline 7 & $\mathrm{Rh}_{2}(\mathrm{esp})_{2}$ & DCE & 100 & 100 & $40: 60$ \\
\hline 8 & $\mathrm{Rh}_{2}(\mathrm{esp})_{2}$ & $\mathrm{CHCl}_{3}$ & 80 & 100 & $75: 25$ \\
\hline 9 & $\mathrm{Rh}_{2}(\mathrm{esp})_{2}$ & $\mathrm{CHCl}_{3}$ & 60 & NR & - \\
\hline
\end{tabular}

NR: no reaction. oct: $n-\mathrm{C}_{7} \mathrm{H}_{15} \mathrm{COO}$. esp: $\alpha, \alpha, \alpha^{\prime}, \alpha^{\prime}$-tetramethyl-1,3-benzenedipropionate. pfb: $n-\mathrm{C}_{3} \mathrm{~F}_{7} \mathrm{COO}$. a Conversion of 1 a was determined by ${ }^{19} \mathrm{~F}$ NMR spectroscopy. ${ }^{\mathrm{b}}$ The same result was observed in the presence of $\mathrm{CF}_{3} \mathrm{COOAg}(5 \mathrm{~mol} \%)$ in addition to $\mathrm{Rh}_{2}(\mathrm{oct}){ }_{4}(1 \mathrm{~mol} \%)$.

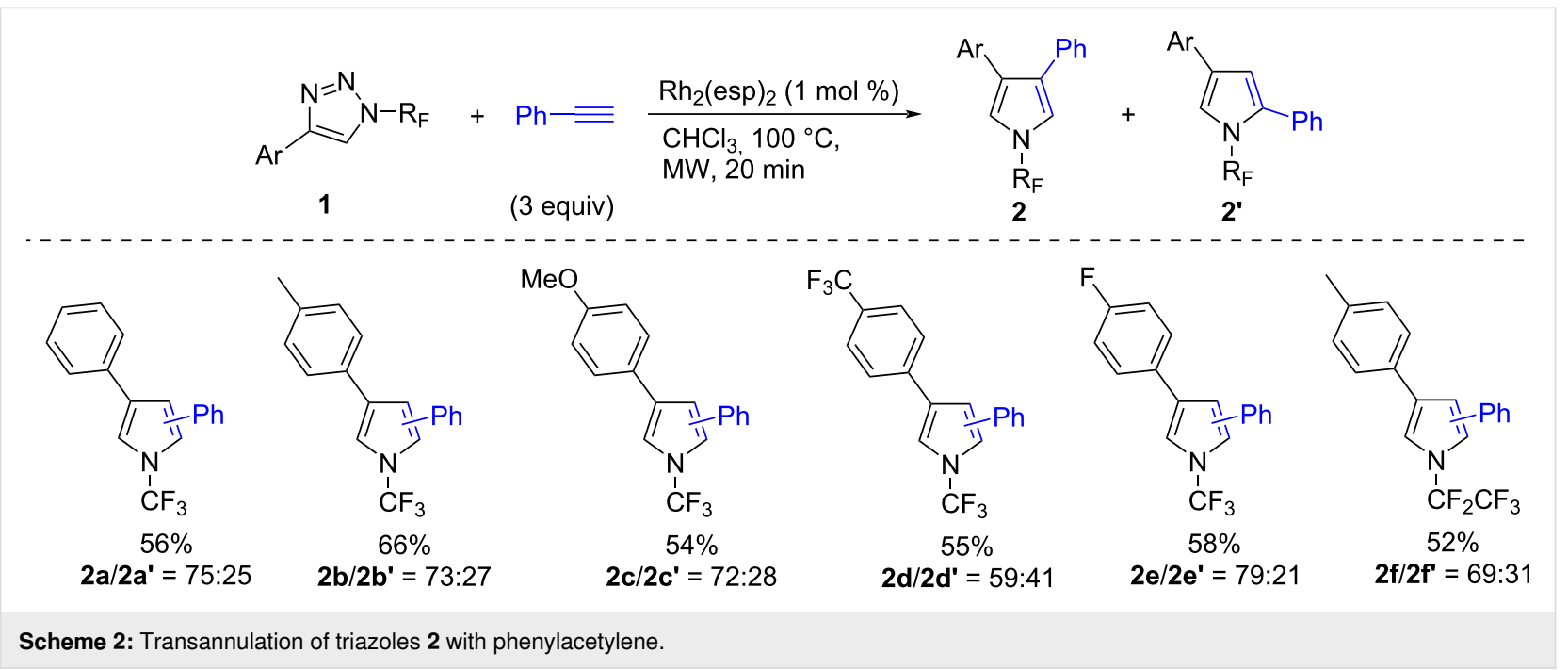


to moderate yields of product mixtures $\mathbf{2}$ and $\mathbf{2}$ ' were obtained and the $\mathbf{2} / \mathbf{2}$ ' ratio ranged from 59:41 to $79: 21$.

While aliphatic alkynes were found to be ineffective in transannulations with $N$-tosyl-1,2,3-triazoles, the reactions of $N$-perfluoroalkyl-1,2,3-triazoles with aliphatic alkynes proceeded well and the pyrroles 3 were formed in unexpectedly high selectivities, ranging from 87:13 to 98:2 (Scheme 3). The isolated product yields were moderate to good and the products were generally obtained as mixtures of regioisomers. Column chromatography allowed the separation of pure isomers of $\mathbf{2 a}, \mathbf{2 a}$, 3a, 3b, 3d, 3h, 3l, 3m, and 3n. However, no general trend in the efficiency of the reaction or product selectivity was observed.
Hex-5-ynenitrile was used in the transannulation with 1a with the aim to assess the relative propensity of nitrile and alkyne groups in the reaction. The triple bond reacted in the transannulation about two times faster than the nitrile group and again the 3,4-disubstituted pyrrole 4 regioisomer dominated over the 2,4disubstitued pyrrole 4' (Scheme 4).

To demonstrate the compatibility of the formed $\mathrm{N}$-perfluoroalkylpyrroles with the conditions of pyrrole derivatization by metalation in position two and reaction with an electrophile, the crude product $\mathbf{2 a}$ was treated with butyllithium, followed by the reaction with carbon dioxide to afford pyrrole carboxylic acid 6 in a good overall yield (Scheme 5). The trifluoromethyl group

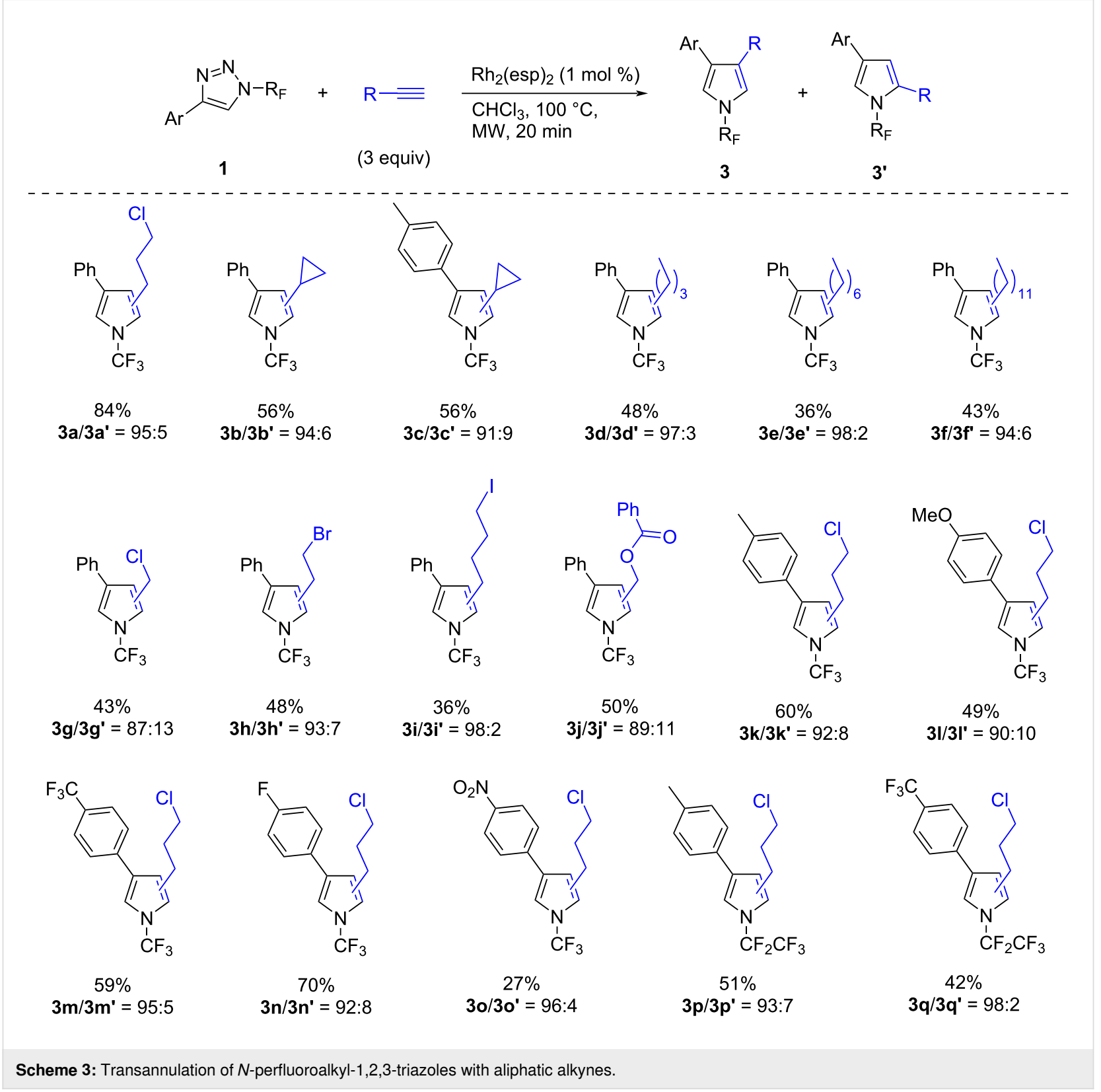


<smiles>[C+]#CCCCC#C[C+]n1cc(-c2ccccc2)nn1</smiles>

$1 a$

\section{$\underset{\mathrm{Rh}_{2}(\mathrm{esp})_{2}(1 \mathrm{~mol} \%)}{\longrightarrow}$ $\mathrm{MW}, 20 \mathrm{~min}$}<smiles>N#CCCCc1cn(C(F)(F)F)cc1-c1ccccc1</smiles>

$4,32 \%$<smiles>N#CCCCc1cc(-c2ccccc2)cn1C(F)(F)F</smiles>

$4^{\prime}$

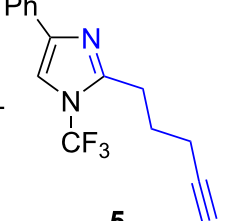

5

$4 / 4^{\prime} / 5=63: 6: 31$

Scheme 4: Reaction of 1a with hex-5-ynenitrile.<smiles>FC(F)(F)n1cc(-c2ccccc2)nn1</smiles>

1a
1. phenylacetylene (3 equiv), $\mathrm{Rh}_{2}(\mathrm{esp})_{2}(1 \mathrm{~mol} \%)$, $\mathrm{CHCl}_{3}, 100{ }^{\circ} \mathrm{C}, \mathrm{MW}, 20 \mathrm{~min}$
2. evaporate solvent, THF,
$n$-BuLi ( 2 equiv), $-78^{\circ} \mathrm{C}, 30 \mathrm{~min}$

3. $\mathrm{CO}_{2}$ (excess), $-78^{\circ} \mathrm{C}, 15 \mathrm{~min}$

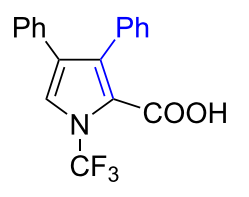

6, $75 \%$

Scheme 5: Metalation and carboxylation of in situ-prepared pyrrole 2a.

on the nitrogen was not affected by these highly basic reaction conditions.

The mechanism of the rhodium-catalyzed transannulation to pyrroles has recently been investigated computationally with $\mathrm{N}$-sulfonyltriazoles [31]. It seems that the formed rhodium carbenoid $\mathbf{B}$ reacts with the alkyne in a concerted process and even in the presence of $\mathrm{Ag}^{+}$salts, a nucleophilic addition of silver acetylides does not take place. In our case, the transition states TS1 and TS2 have roughly similar energies for phenylacetylene and TS1 is lower in energy for aliphatic alkynes (Scheme 6).

\section{Conclusion}

In conclusion, the rhodium-catalyzed transannulation of $N$-perfluoroalkyl-1,2,3-triazoles with terminal alkynes was described. The reaction led to a mixture of the $\mathrm{N}$-perfluoroalkyl-3,4- and 2,4-disubstituted pyrroles. The reactions with phenylacetylene afforded a mixture of 3,4- and 2,4-disubstituted pyrroles in a ratio from 59:41 to 79:21, while the reactions with aliphatic acetylenes gave higher product regioselectivities (87:13 to 98:2). This is the first report of a transannulation leading to 3,4disubstituted pyrroles. Additionally, the method did not require the use of a silver(I) co-catalyst. The scope for aliphatic alkynes is reasonably wide and the isolated yields were moderate to

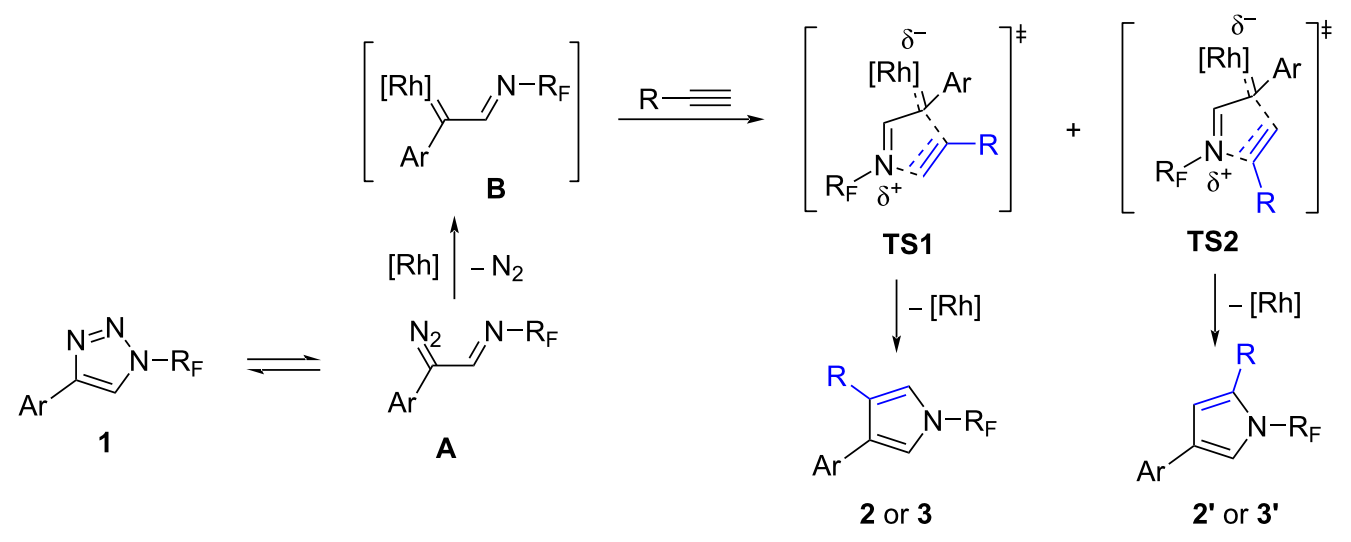


good. A one-pot transannulation/carboxylation process was demonstrated for the construction of the functionalized pyrrole 2-carboxylic acid with an $\mathrm{N}$-trifluoromethyl functionality. Thus, this work improves the synthetic access to $N$-perfluoroalkyl-3,4disubstituted pyrroles.

\section{Supporting Information}

\section{Supporting Information File 1}

Experimental part.

[https://www.beilstein-journals.org/bjoc/content/

supplementary/1860-5397-17-44-S1.pdf]

\section{Funding}

This work was financially supported by the Czech Academy of Sciences (Research Plan RVO: 61388963) and by the Ministry of Education, Youth and Sports in the program INTEREXCELLENCE (LTAUSA18037).

\section{ORCID ${ }^{\circledR}$ iDs}

Olga Bakhanovich - https://orcid.org/0000-0002-2381-9030 Viktor Khutorianskyi - https://orcid.org/0000-0003-0994-7498 Vladimir Motornov - https://orcid.org/0000-0002-4951-8113 Petr Beier - https://orcid.org/0000-0002-0888-7465

\section{References}

1. Gupton, J. T. Top. Heterocycl. Chem. 2006, 2, 53-92. doi:10.1007/7081_019

2. Guernion, N. L.; Hayes, W. Curr. Org. Chem. 2004, 8, 637-651. doi:10.2174/1385272043370771

3. Bhardwaj, V.; Gumber, D.; Abbot, V.; Dhiman, S.; Sharma, P. RSC Adv. 2015, 5, 15233-15266. doi:10.1039/c4ra15710a

4. Kaur, R.; Manjal, S. K.; Rawal, R. K.; Kumar, K. J. Pharm. Chem. Chem. Sci. 2017, 1, 17-32.

5. Joule, J. A.; Keith, M. Heterocyclic Chemistry, 5th ed.; John Wiley \& Sons: Chichester, UK, 2010.

6. Leeper, F. J.; Kelly, J. M. Org. Prep. Proced. Int. 2013, 45, 171-210. doi:10.1080/00304948.2013.786590

7. Bellina, F.; Rossi, R. Tetrahedron 2006, 62, 7213-7256. doi:10.1016/j.tet.2006.05.024

8. Davies, H. M. L.; Alford, J. S. Chem. Soc. Rev. 2014, 43, 5151-5162. doi:10.1039/c4cs00072b

9. Chattopadhyay, B.; Gevorgyan, V. Angew. Chem., Int. Ed. 2012, 51, 862-872. doi:10.1002/anie.201104807

10. Anbarasan, P.; Yadagiri, D.; Rajasekar, S. Synthesis 2014, 46, 3004-3023. doi:10.1055/s-0034-1379303

11. Chattopadhyay, B.; Gevorgyan, V. Org. Lett. 2011, 13, 3746-3749. doi:10.1021/ol2014347

12. Kim, C.-E.; Park, S.; Eom, D.; Seo, B.; Lee, P. H. Org. Lett. 2014, 16, 1900-1903. doi:10.1021/ol500718s

13. Rajasekar, S.; Anbarasan, P. J. Org. Chem. 2014, 79, 8428-8434. doi:10.1021/j0501043h
14. Parr, B. T.; Green, S. A.; Davies, H. M. L. J. Am. Chem. Soc. 2013, 135, 4716-4718. doi:10.1021/ja401386z

15. Lei, X.; Li, L.; He, Y.-P.; Tang, Y. Org. Lett. 2015, 17, 5224-5227. doi:10.1021/acs.orglett.5b02570

16. Miura, T.; Hiraga, K.; Biyajima, T.; Nakamuro, T.; Murakami, M. Org. Lett. 2013, 15, 3298-3301. doi:10.1021/ol401340u

17. Miura, T.; Yamauchi, M.; Murakami, M. Chem. Commun. 2009, 1470-1471. doi:10.1039/b819162j

18. Blastik, Z. E.; Voltrová, S.; Matoušek, V.; Jurásek, B.; Manley, D. W.; Klepetářová, B.; Beier, P. Angew. Chem., Int. Ed. 2017, 56, 346-349. doi:10.1002/anie.201609715

19. Motornov, V.; Markos, A.; Beier, P. Chem. Commun. 2018, 54 , 3258-3261. doi:10.1039/c8cc01446a

20. Motornov, V.; Beier, P. J. Org. Chem. 2018, 83, 15195-15201. doi:10.1021/acs.joc.8b02472

21. Motornov, V.; Koštál, V.; Markos, A.; Täffner, D.; Beier, P. Org. Chem. Front. 2019, 6, 3776-3780. doi:10.1039/c9qo01104h

22. Tichý, D.; Koštál, V.; Motornov, V.; Klimánková, I.; Beier, P. J. Org. Chem. 2020, 85, 11482-11489. doi:10.1021/acs.joc.0c01610

23. O'Hagan, D. J. Fluorine Chem. 2010, 131, 1071-1081. doi:10.1016/j.jluchem.2010.03.003

24. Han, J.; Remete, A. M.; Dobson, L. S.; Kiss, L.; Izawa, K.; Moriwaki, H. Soloshonok, V. A.; O'Hagan, D. J. Fluorine Chem. 2020, 239, 109639. doi:10.1016/j.jluchem.2020.109639

25. Zhou, Y.; Wang, J.; Gu, Z.; Wang, S.; Zhu, W.; Aceña, J. L.; Soloshonok, V. A.; Izawa, K.; Liu, H. Chem. Rev. 2016, 116, 422-518. doi:10.1021/acs.chemrev.5b00392

26. Wang, J.; Sánchez-Roselló, M.; Aceña, J. L.; del Pozo, C.; Sorochinsky, A. E.; Fustero, S.; Soloshonok, V. A.; Liu, H. Chem. Rev. 2014, 114, 2432-2506. doi:10.1021/cr4002879

27. Purser, S.; Moore, P. R.; Swallow, S.; Gouverneur, V. Chem. Soc. Rev. 2008, 37, 320-330. doi:10.1039/b610213c

28. Meanwell, N. A. J. Med. Chem. 2018, 61, 5822-5880. doi:10.1021/acs.jmedchem.7b01788

29. Schiesser, S.; Chepliaka, H.; Kollback, J.; Quennesson, T.; Czechtizky, W.; Cox, R. J. J. Med. Chem. 2020, 63, 13076-13089. doi:10.1021/acs.jmedchem.0c01457

30. Scattolin, T.; Bouayad-Gervais, S.; Schoenebeck, F. Nature 2019, 573, 102-107. doi:10.1038/s41586-019-1518-3

31. Zhang, Z.; Yang, S.; Li, J.; Liao, X. J. Org. Chem. 2016, 81, 9639-9646. doi:10.1021/acs.joc.6b01706 


\section{License and Terms}

This is an Open Access article under the terms of the Creative Commons Attribution License (https://creativecommons.org/licenses/by/4.0). Please note that the reuse, redistribution and reproduction in particular requires that the author(s) and source are credited and that individual graphics may be subject to special legal provisions.

The license is subject to the Beilstein Journal of Organic Chemistry terms and conditions:

(https://www.beilstein-journals.org/bjoc/terms)

The definitive version of this article is the electronic one which can be found at:

https://doi.org/10.3762/bjoc.17.44 